\title{
ПІДГОТОВКА МАЙБУТНІХ МЕДИЧНИХ СЕСТЕР ДО ЗДОРОВ'ЯЗБЕРЕЖУВАЛЬНОЇ ДІЯЛЬНОСТІ З ВАЖКОВИХОВУВАНИМИ ПІДЛІТКАМИ
}

\author{
І. М. Мельничук, В. Ю. Морванюк \\ ДВНЗ «Тернопільський державний медичний університет \\ імені І. Я. Горбачевського МОЗ Украӥни" \\ Уманський медичний коледж
}

У статті висвітлено питання запровадження інноваційних методів у роботу медичних сестер для організації оптимальної взаємодії з важковиховуваними підлітками з метою продуктивного впливу на них у напрямі підготовки до здоров’язбережувальної діяльності.

\section{FUTURE NURSES' TRAINING FOR HEALTH SAVING WORK WITH TROUBLED ADOLESCENTS}

\author{
I. M. Melnychuk, V. Yu. Morvaniuk \\ I. Horbachevsky Ternopil State Medical University \\ Uman Medical College
}

The issue of innovative methods introduction in the work of nurses for the organization of optimal interaction with troubled adolescents with the aim of productive impact on them towards training for health saving activities is discussed in the article.

Вступ. У сучасних умовах загострення суспільних суперечностей в Україні часто спостерігаються процеси соціальної деформації особистості, що супроводжуються такими асоціальними явищами, як алкоголізм, токсикоманія, наркоманія, проституція. Особливо вразливою групою, яка піддається впливу цих негативних явищ, визначено підростаюче покоління, в результаті чого майже 60 \% підлітків відносять до категорії важковиховуваних дітей. Вирішення цієї проблеми є одним із стратегічних загальнонаціональних пріоритетів державної політики України, що зазначено в Законі України «Про охорону дитинства», Указі Президента України «Про додаткові заходи щодо забезпечення виконання Національної програми «Діти України» на період до 2005 року» та в інших нормативно-правових актах [1].

Проблема організації психолого-педагогічної та медичної роботи в напрямі здоров'язбереження підлітків була предметом вивчення в працях А. Макаренка, О. Сухомлинського, Л. Виготського, П. Лесгафта, Ч. Ломброзо та інших педагогів, психологів, фахівців

() І. М. Мельничук, В. Ю. Морванюк, 2017 фізичної культури, соціальних і медичних працівників. Негативні прояви асоціальної поведінки у дітей підліткового віку актуалізують використання комплексних заходів із залученням представників медичної спільноти, до якої належать і медичні сестри, котрі працюють в школах та лікувальних установах.

Основна частина. У професійній діяльності медичної сестри в напрямі організації здоров'язбережувальної роботи з підлітками важливо знайти механізми впливу на свідомість дитини з метою надання не лише якісної медичної, а й психолого-педагогічної допомоги. У цьому сенсі важливим є підготовка майбутніх медичних сестер до такої діяльності, що сприятиме налагодженню контакту на рівні «медична сестра - підліток», «медична сестра - педагог», «медична сестра - батьки дитини», що визначаємо основним завданням цієї статті.

3 метою конкретизації напрямів і методики організації міжособистісної взаємодії на зазначених рівнях уточнимо сутність ключових понять.

Важковиховувані діти - це такі категорії дітей, у яких при довготривалому впливі несприятливого середо- 
вища для їхнього психофізичного та соціального становлення розвиваються якісні зміни в поведінці [2].

Важковиховувані підлітки - це, за визначенням Л. Виготського, «важкі діти» [3], якиху наш час нараховується більше половини від усієї кількості школярів. Такі підлітки, переживаючи критичні періоди свого розвитку, неначе випадають з тієї системи педагогічного впливу, яка ще зовсім недавно забезпечувала нормальний хід їхнього виховання і навчання.

Звичайно такі діти розвиваються в особливому соціальному оточенні, неповноцінному за структурою (відсутність одного з батьків, соціальна некомпетентність самих батьків і педагогів тощо). Низький культурно-освітній рівень батьків, слабка культура сімейного виховання, а пізніше - педагогічного процесу, недостатня загальна культура навколишнього мікросередовища, яке оточує дитину, в тому числі й в умовах, коли підліток спілкується з фахівцями медицини, $є$ гальмівним процесом нормального культурного, психоемоційного, психофізіологічного розвитку та соціалізації дитини в підлітковому віці. Варто також відзначити, що лінії біологічного, соціального і культурного розвитку підлітка $є$ взаємозалежними і взаємозумовленими. Тому актуалізується реалізація комплексного підходу для здійснення виховного впливу на важковиховуваних підлітків не лише з боку батьків і педагогів, а й медичного персоналу, зокрема медичних сестер, які контактують з дітьми цієї вікової категорії.
3 метою оптимізації налагодженню контактів фахівців медсестринства з такими підлітками необхідно підготувати майбутніх медичних сестер до означеної діяльності. Зокрема, доцільним буде використання ними методик для визначення рівня важковиховуваності у дітей, з якими доведеться контактувати медичній сестрі в школі чи у лікувальному закладі. Пропонуємо медичним сестрам на етапі знайомства з підлітками використовувати опитувальник для заповнення карти визначення типу та рівня важковиховуваності.

У таблиці подано показники характерологічних особливостей дитини, її поведінки, спілкування, що свідчать про наявність конкретного типу важковиховуваності.

Заповнюючи карту, медична сестра має змогу визначити ступінь вираженості кожної особливості (ні - 0 балів, так - 2 бали, може бути - 1).

Аналізуючи результати опитування при першому знайомстві з підлітками можна встановити типи важковиховуваності підлітків, що надалі доцільно враховувати медичному персоналу в спілкуванні з такими дітьми.

1. Тип педагогічно занедбаних дітей. Вони виявляють низький рівень розвитку моральних уявлень та соціально схвалених навичок поведінки.

2. Конституціональний тип. Труднощі у вихованні таких підлітків зумовлені індивідуально-психологічними особливостями особистості (акцентуації характеру, емоційна нестійкість, імпульсивність).

Таблиця. Карта визначення типу та рівня важковиховуваності

\begin{tabular}{|c|l|c|}
\hline № за/п & \multicolumn{1}{|c|}{ Критерії визначення типу та рівня важковиховуваності } & Бали \\
\hline 1 & Невпевнений у собі & \\
\hline 2 & Погана дисципліна & \\
\hline 3 & Чутливо реагує на зауваження & \\
\hline 4 & Низький рівень засвоєння навчальної програми & \\
\hline 5 & Низький рівень інтелектуального розвитку & \\
\hline 6 & Непопулярний серед однолітків & \\
\hline 7 & Несформованість навичок спілкування & \\
\hline 8 & Низький рівень культури в родині & \\
\hline 9 & Неблагополучна, неповна сім'я & \\
\hline 10 & Батьки не займаються вихованням дитини & \\
\hline 11 & Імпульсивний, непосидючий & \\
\hline 12 & Задиркуватий & \\
\hline 13 & Упертий & \\
\hline 14 & Схильний до лідерства, домінуючий & \\
\hline 15 & Самолюбивий & \\
\hline 16 & Неорганізований & \\
\hline 17 & Недисциплінований & \\
\hline 18 & Слабовільний & \\
\hline 19 & Дратівливий & \\
\hline 20 & Неуважний & \\
\hline
\end{tabular}


Продовження табл.

\begin{tabular}{|l|l|c|}
\hline № за/п & \multicolumn{1}{|c|}{ Критерії визначення типу та рівня важковиховуваності } & Бали \\
\hline 21 & Випереджувальний фізичний розвиток & \\
\hline 22 & Часті зміни самопочутяя & \\
\hline 23 & Нормальний рівень інтелектуального розвитку & \\
\hline 24 & Підвищена зацікавленість до навколишнього світу & \\
\hline 25 & Вибіркова конфліктність & \\
\hline 26 & Самостійність & \\
\hline 27 & Прагнення здаватись дорослішим, ніж є насправді & \\
\hline 28 & Підвщена критичність до інших & \\
\hline 29 & Підвищена самокритичність & \\
\hline 30 & Схильність до перепадів активності & \\
\hline 31 & Смислова закритість щодо педагогічних впливів & \\
\hline 32 & Неадекватно високі домагання & \\
\hline 33 & Несприятливе становище в колективі & \\
\hline 34 & Неадекватний спокій щодо відчуження у спілкуванні & \\
\hline 35 & Підвищена вразливість & \\
\hline 36 & Злопам'ятність & \\
\hline 37 & Цинічність & \\
\hline 38 & Брехливість & \\
\hline 39 & Негативна реакція на зауваження & \\
\hline 40 & Грубі порушення дисципліни. Зловмисна агресивність & \\
\hline
\end{tabular}

3. Ситуативний тип - зумисні дії, які призводять до конфліктів (несправжня важковиховуваність).

4. Тип важковиховуваних дітей - труднощі у вихованні, які призводять до протидії виховному впливу:

- феномен не смислового бар'єра;

- феномен «афекту неадекватності»;
- розгалуженість взаємин у домінуючих сферах уяви та дійсності.

Після заповнення карти визначення типу та рівня важковиховуваності підлітків необхідно підрахувати кількість балів і встановити тип і ступінь важковиховуваності за шкалою:

\begin{tabular}{|l|l|c|}
\hline \multicolumn{1}{|c|}{ Тип важковиховуваності } & $\begin{array}{c}\text { Наявні показники кожного типу } \\
\text { важковиховуваності }\end{array}$ & Сума балів \\
\hline Педагогічно занедбані діти & $1,2,3,4,5,6,7,8,9,10$ & \\
\hline Конституціональний тип & $11,12,13,14,15,16,17,18,19,20$ & \\
\hline Ситуативний тип & $21,22,23,24,25,26,27,28,29,30$ & \\
\hline Важковиховувані діти & $31,32,33,34,35,36,37,38,39,40$ & \\
\hline
\end{tabular}

Висновки. На основі аналізу отриманих цифрових показників медична сестра має змогу зробити підсумок: тип важковиховуваності визначається за найбільшою сумою набраних балів згідно з таблицею. Якщо різні типи важковиховуваності оцінено однаковою кількістю балів, визначається змішаний тип (наприклад, 7 балів - ситуативний та 7 балів конституціональний; тип важковиховуваності - ситуативно-конституціональний). Рівень важковихову-

\section{СПИСОК ЛІТЕРАТУРИ}

1. Сімейне законодавство України. Збірник законодавчих та підзаконних актів. - К. : Атіка, 2003. - 512 с.

2. Хромова О. В. Сухомлинський про виховання важких дітей і підлітків / О. В. Хромова // Наукові записки ваності: 0-6 балів - низький; 7-12 балів - середній; 13-20 балів - високий.

Отримані дані медична сестра може використовувати для організації оптимальної взаємодії з підлітками та продуктивного впливу на них у напрямі підготовки до здоров'язбережувальної діяльності.

Перспективи подальших досліджень у даному напрямку вбачаємо у розробці нових методик підготовки майбутніх медичних сестер до здоров'язбережувальної діяльності з підлітками.

ТдпУ ім. В. Гнатюка : Педагогіка. - 2002. - Вип. 5. С. 149-151.

3. Выготский Л. С. Трудное детство / Л. С. Выготский. М. : Изд. МГУ, 1995. - 159 с. 